\title{
Is regional paediatric surveillance useful? Experience in Wales
}

\begin{abstract}
J R Sibert, R J H Morgan, H I O'Connell, R Lynn, Z E Guildea, S R Palmer, and the Welsh Paediatric Society-WPSU study group
\end{abstract}

\begin{abstract}
The Welsh Paediatric Surveillance Unit was established in 1994 to monitor the incidence and prevalence of a number of uncommon disorders of childhood in Wales. Its work complements that of the British Paediatric Surveillance Unit. Information from consultant paediatricians is obtained by means of a monthly card return system; return rate is over $\mathbf{9 0 \%}$. (Arch Dis Child 2001;84:486-487)
\end{abstract}

Keywords: surveillance; Wales

The identification and surveillance of rare conditions in childhood has long been an aim of those promoting child health. In 1986, the British Paediatric Surveillance Unit (BPSU) ${ }^{12}$ began enabling paediatricians to participate in the surveillance of infectious disease and uncommon disorders in childhood. It uses a monthly card return system to consultant paediatricians and has been the stimulus for a number of other national surveillance systems throughout the world. ${ }^{3}$ We believed there was a need for a child health surveillance system that was available for the devolved Health Service in Wales, both for public health and health management issues, and for audit and research. To address this the Welsh Paediatric Surveillance

Table 1 WPSU projects

\begin{tabular}{|c|c|c|c|c|c|}
\hline Project & Researcher & $\begin{array}{l}\text { Study } \\
\text { number }\end{array}$ & $\begin{array}{l}\text { Incidence in Wales* } \\
\text { (per } 100 \text { 000) }\end{array}$ & $\begin{array}{l}\text { Start } \\
\text { date }\end{array}$ & $\begin{array}{l}\text { Finish } \\
\text { date }\end{array}$ \\
\hline Acute renal failure & Kate Verrier-Jones & 1 & $5.0(\mathrm{CI} \pm 1.6)$ & $01 / 07 / 94$ & $30 / 9 / 97$ \\
\hline Congenital adrenal hyperplasia & John Gregory & 2 & $6.7(\mathrm{CI} \pm 1.1)$ (prevalence $0-18$ years) & $01 / 07 / 94$ & $31 / 12 / 99$ \\
\hline Household product poisoning & Jo Sibert & 3 & Unsuccessful & $01 / 07 / 94$ & $31 / 03 / 95$ \\
\hline Chronic renal failure & Kate Verrier-Jones & 4 & $9.3(\mathrm{CI} \pm 1.1)$ & $01 / 07 / 94$ & $30 / 09 / 97$ \\
\hline Coeliac disease & Huw Jenkins & 5 & $\begin{array}{l}2.4(\mathrm{CI} \pm 0.9) \\
\text { New cases }\end{array}$ & $01 / 01 / 95$ & $28 / 02 / 97$ \\
\hline Haemoglobinopathy & Marianne Phillips & 6 & Unsuccessful & $01 / 01 / 95$ & $28 / 02 / 97$ \\
\hline Inflammatory bowel disease & Huw Jenkins & 7 & $\begin{array}{l}2.1(\mathrm{CI} \pm 0.8) \\
\text { New cases }\end{array}$ & $01 / 01 / 95$ & $28 / 02 / 97$ \\
\hline The critically ill child & Graham Shortland & 8 & $20.7(\mathrm{CI} \pm 2.4)(0-16$ years $)$ & $01 / 10 / 95$ & $30 / 09 / 97$ \\
\hline Severe physical child abuse & Jo Sibert & 9 & $\begin{array}{l}114 \mathrm{CI} \pm 11.8)(\text { babies under } 1) \\
\text { All physical abuse }\end{array}$ & $01 / 01 / 96$ & $31 / 03 / 98$ \\
\hline Childhood tuberculosis & Mazin Alfaham & 10 & $\begin{array}{l}1.6(\mathrm{CI} \pm 0.6) \text { (confirmed cases) } \\
2.0(\mathrm{CI} \pm 0.7) \text { (chemoprophylaxis) }\end{array}$ & $01 / 09 / 96$ & Ongoing \\
\hline Marfan's syndrome & $\begin{array}{l}\text { Graham Stuart, then } \\
\text { Sally Davies }\end{array}$ & 11 & $\begin{array}{l}0.4(\mathrm{CI} \pm 0.28) \\
\text { New referrals }\end{array}$ & $01 / 09 / 96$ & $30 / 6 / 00$ \\
\hline Children in house fires & Jean Matthes, Swansea & 12 & $23.0(\mathrm{CI} \pm 3.8)$ & $01 / 01 / 98$ & $31 / 12 / 99$ \\
\hline Subdural haemorrhage & Alison Kemp & 13 & $34.0(\mathrm{CI} \pm 19.2)$ (babies under 6 months) & $01 / 01 / 98$ & $31 / 03 / 98$ \\
\hline Newly diagnosed diabetes & Mike Maguire & 14 & Not yet available & $01 / 07 / 98$ & Ongoing \\
\hline Newly diagnosed malignant disease & Meriel Jenney & 15 & $10.0(\mathrm{CI} \pm 2.5)$ & $01 / 01 / 99$ & $31 / 12 / 00$ \\
\hline Subdural haemorrhage & Alison Kemp & 16 & $34(\mathrm{CI} \pm 19.2)$ (babies under 6 months) & $01 / 04 / 99$ & Ongoing \\
\hline Facial palsy & Catherine Norton & 17 & Not yet available & $01 / 01 / 00$ & Ongoing \\
\hline
\end{tabular}

${ }^{\star} 0-13$ years unless stated.
Unit (WPSU) was established in 1994 to complement the work of the BPSU.

\section{Methods and results}

The WPSU uses the same methodology that had been successful with the BPSU. ${ }^{12}$ The cards are green with a daffodil symbol to prevent confusion. Cards are distributed each month to consultant paediatricians and senior clinical medical officers in Wales (there are approximately 100) and are sent back even if there are no cases to report. The appropriate investigator is informed, who contacts the reporting paediatrician for further information. Table 1 shows the 17 projects that have been accepted by the WPSU and estimates of their incidence or prevalence. Studies have provided information

We have assessed the usefulness of the WPSU according to guidelines published by the Centers for Disease Control in Atlanta. ${ }^{4}$ It has fulfilled the majority of the criteria. Only two of the studies failed to complete. The researchers of the 10 studies completed judged them as providing valuable results. The studies on renal ascertainment from other sources.

As a result of our work, actions have been taken on the health of children in Wales. They have included the establishment of a paediatric on health care planning, audit, and research. failure at the start of the WPSU needed extra

Centre, Llandough

Hospital, Penarth

CF64 2XX, UK

J R Siber

H I O'Connell

Z E Guildea

S R Palmer

Department of Child

Health, Royal

Glamorgan Hospital,

Ynys Maerdy,

Llantrisant CF72 8XR, UK

R J H Morgan

British Paediatric Surveillance Unit,

50 Hallam Street,

London W1W 6DE, UK

R Lynn

Correspondence to:

Prof. Sibert

sibert@cf.ac.uk 
intensive care unit in Wales and management criteria for subdural haematoma. We have found the WPSU simple to manage, as it is part of the Welsh Paediatric Society. The positive card returns indicate that Welsh paediatricians have accepted it. The National Assembly for Wales has also accepted it for partial central funding.

We have analysed card returns from the WPSU and the BPSU: both systems have good card return rates of well over $90 \%$. Statistically, rates of card return were better with the WPSU than the BPSU in $1996(\mathrm{p}<0.001)$ and 1999 $(\mathrm{p}<0.01)$ and no different in 1997 and 1998. There has been a steady improvement in the card returns in Wales from the BPSU over the years. Comparing 1995 (93.9\%) with 1999 $(97.6 \%)$, the returns have improved significantly $(\mathrm{p}<0.001)$. The ranking of Wales compared to other regions in the British Isles for the BPSU has improved from 12th of 20 regions in 1995 to first in 1999.

\section{Conclusions}

The WPSU has now been in existence for six years. We have shown that the system works and that we are now accepted as useful by Welsh paediatricians and also by the National Assembly. Paediatricians return their cards at a similar (and indeed better) rate to the UK BPSU system. We believe that "ownership" of the project by Welsh paediatricians has been vital for its success. Response rates in Wales to the BPSU have improved during the existence of the WPSU and we believe that the WPSU could have improved the understanding and appreciation of Welsh paediatricians in surveillance. We believe it could be a model for similar work in the UK and in European countries with small child populations.

We thank the Wales Office of Research and Development Grant, the Welsh Office, the Welsh Paediatric Society, the University of Wales College of Medicine, and the National Assembly for Wales for funding. We particularly thank Eileen Derby for all her work on the initial two years of the WPSU. Members of the Welsh Paediatric Society-WPSU study group: MA Alfaham, P Welsh Paediatric Society-WPSU study group: MA Alfaham, P
Buss, DP Davies, C Graham, JW Gregory, HR Jenkins, MEM Jenney, AM Kemp, R Lyons, JWA Matthes, K Kontos, MJ Maguire, C Norton, RT Rangarajan, GJ Shortland, K Verrier-Jones.

1 Hall SM, Nicoll A. The British Paediatric Surveillance Unit-a pioneering method for investigating the less common disorders of childhood. Child Care Health Dev mon disorders

2 Lynn R, Nicoll A, et al, eds. British Paediatric Surveillance Unit. Annual report for 1998/99. London: RCPCH, 1999.

3 Gazarian M, Williams K, Elliott E, et al. Evaluation of a national surveillance unit. Arch Dis Child 1999;80:21-7.

4 Klauke DN, Buehler JW, Thacker SB, et al. Centers for Disease Control and Prevention. Guidelines for evaluating surveillance systems. MMWR Morb Mortal Wkly Rep 1988; 37(suppl 5):1-18

\section{Rapid responses}

Letters on the following papers have been published recently as rapid responses on the $A D C$ website. To read these letters visit www.archdischild.com and click on "Read rapid responses":

Prophylaxis for respiratory syncytial virus infection: missing the target. JJ Buck, P Debenham, RC Tasker. Arch Dis Child 2001;84:373.

Pancreatic dysfunction in severe obesity. AJ Drake, L Greenhalgh, R Newbury-Ecob, et al. Arch Dis Child $2001 ; 84: 261-2$.

A review of measures of quality of life for children with chronic illness. C Eiser, R Morse. Arch Dis Child 2001;84:205-11.

Chronic musculoskeletal and other idiopathic pain syndromes. PN Malleson, H Connell, SM Bennett, et al. Arch Dis Child 2001;84:189-92.

Calibration of the paediatric index of mortality in UK paediatric intensive care units. GA Pearson, J Stickley, F Shann. Arch Dis Child 2001;84:125-8.

The management of fever and petechiae: making sense of rash decisions. PA Brogan, A Raffles. Arch Dis Child 2000;83:506-7.

Effect of severity of disability on survival in north east England cerebral palsy cohort. JL Hutton, AF Colver, PC Mackie, et al. Arch Dis Child 2000;83:468-74.

Children's perception of breathlessness in acute asthma. I Male, H Richter, P Seddon. Arch Dis Child 2000;83:325-9.

Capillary refill and core-peripheral temperature gap as indicators of haemodynamic status in paediatric intensive care patients. SM Tibby, M Hatherill, IA Murdoch. Arch Dis Child 1999;80:163-6.

If you would like to post an electronic response to these or any other articles published in the journal, please go to the website, access the article in which you are interested, and click on "eLetters: Submit a reponse to this article" in the box in the top right hand corner. 